\title{
Fungsi Manajemen Diri Siswa SLTP dalam Memahami Pembelajaran Pendidikan Agama Islam (PAI)
}

\author{
Mindani \\ Jurusan Tarbiyah STAIN Syech Jamil Djambek Bukittinggi \\ E-mail: mindani70@gmail.com \\ Hp: 081374333569
}

\begin{abstract}
In this paper the writer discusses the function of students' self management in understanding Islamic learning and tries to relate it with general management function as a controlling system in learning. The indicators of students' self management function will be seen in the following learning process such as the ability to set the goal of learning, monitor and evaluate the learning activity, and provide self reinforcement. Furthermore, it will also discuss about the implementation of student's self management through some indicator; students, school and institution in applying learning management. Afterwards, it will also elaborate about to value, management and Islamic value and applying the student's self management in learning process.
\end{abstract}

Key Words: Self Management, Student, Learning, Islamic Education

\begin{abstract}
Abstrak: Dalam artikel ini penulis akan mendiskusikan fungsi dari manajemen pengendalian diri mahasiswa dalam memahami Pembelajaran Agama Islam (PAI). Dan mencoba menghubungkan dengan fungsi manajemen secara umum sebagai sistem kontrol dalam pembelajaran. Indikator dari fungsi manajemen diri siswa yang terlihat di dalam proses pembelajaran seperti kemampuan menentukan tujuan pembelajaran dan mengevaluasi kegiatan pembelajaran, dan memberikan rangsangan diri. Karena itu,artikel ini juga akan mendiskusikan tentang penerapan manajemen diri siswa melalui beberapa indikator, diantaranya adalah siswa, sekolah, dan institusi didalam menerapkan manajemen pembelajaran. Kemudian, Artikel ini juga akan menjelaskan tentang nilai, manajemen, nilai keislaman dan penerpan manajemen diri siswa didalam pembelajaran.
\end{abstract}

Kata Kunci: Manajemen Diri, Mahasiswa, Pembelajaran, Pendidikan Islam

\section{PENDAHULUAN}

Sebelum pembahasan ini menuju pada manajemen diri siswa, sebelumnya akan penulis singgung sedikit pengertian dan konsep dasar manajemen itu sendiri, secara terminology pengertian manajemen banyak dikemukan oleh ahli manajemen misalnya Siagian (1980) menyatakan bahwa manajemen adalah kemampuan keterampilan untuk memperoleh suatu hasil dalam rangka mencapai tujuan melalui kegiatan-kegiatan orang lain. Sedangkan Donely, dkk (1984) menyebutkan bahwa manajemen adalah sebuah proses yang dilakukan oleh satu orang atau lebih untuk mengatur kegiatan-kegiatan melelui orang lain atau dirinya sendiri sebagai upaya untuk mencapai tujuan yang tidak mungkin dilaksanakan seorang saja. Dari pengertian diatas dapat ditari pemahaman bahwa manjemen diri pada siswa sangat memungkinkan membantu proses dan keberhasilan pembelajaran terutama pada pembelajar tingkatan SLTP dan umum.

Proses pembelajaran secara umum merupakan suatu proses kegiatan di mana elemen-elemen pembelajaran dirangkai atau disusun untuk mencapai tujuan umum pengajaran yang didalamnya terjadi interaksi antara guru dan siswa dalam upaya menumbuhkembangkan pengetahuan siswa. Sebagaimana diketahui bahwa pembelajaran dalam pendidikan berfungsi menambah atau mengembangkan, menumbuhkan dari kecil menjadi besar, memperbaiki menangani urusan serta membimbing dan menjaga. Oleh sebab itu dalam ppembelajaran faktor proses dan pengetahuan yang didukung manajemen adalah sebuah keniscayaan pembelajaran. Dalam tulisan ini penulis akan coba menguraikan dan melihat fungsi dari manajemen diri dalam 
proses pembelajaran PAI sebagai sebuah elemen pembelajaran dan faktor yang menentukan keberhasilan pembelajaran.

Dalam pandangan pembelajaran Behavioral aplikasi terbaru dari teori ini adalah mengungkap manajemen diri yang berperan dalam membantu siswa agar mampu mengontrol kegiatan belajarnya. Dan manajemen diri sebagai sebuah tanggung jawab dan kemampuan belajar pada diri siswa. Siagian (1980) menyatakan bahwa tidak ada orang yang mampu untuk belajar demi kepentingan orang lain salah satu alasan pandangan teori behavioral tertarik dengan menerapkan manajemen diri dalam proses pembelajaran adalah karena siswa diajar dengan metode perilaku klasik sehingga sangat jarang menggeneralisasikan hasil belajarnya pada situasi baru. Mendorong siswa agar melakukan manajemen didri memang memerlukan waktu tambahan, karena pendidik mengajarkan bagaimana peserta didik dibimbing untuk bertanggungjawab pada dirinya, tetapi apabila pendidik melupakan pembinaan manajemen diri bagi siswa maka siswa akan kesulitan belajar dan bekerja secara independen, setelah mereka berada pada sekolah yang memiliki manajemen yang bagus.

\section{PEMBAHASAN}

\section{Deskripsi Teori tentang Manajemen Diri}

Manajemen diri secara umum terdiri dari tiga langkah utama yaitu, menentukan tujuan, memonitor dan mengevaluasi kemajuan, dan memberikan penguatan diri. Apabila tujuan pendidikan untuk menghasil-kan orang-orang yang mampu mendidik dirinya maka siswa harus belajar mengatur hidupnya dengan menetukan tujuannya sendiri, memonitor dan mengevaluasi perilakunya, dan menyediakan penguatan untuk dirinya. Siswa mungkin terlibat dalam beberapa atau semua langkah untuk mengimplementasikan program pembelaja-ran, maka pada kondisi ini siswa harus bisa membantu dirinya untuk menentukan tujuan,mengobservasi pekerjaannya sendiri mencatat perkembangan, dan mengevaluasi kinerjanya sendiri. Akhirnya mereka dapat memilih dan memberikan penguatan untuk dirinya sendiri. Keterlibatan seperti ini dapat membantu siswa belajar mengatur langkah kerjanya di masa datang sehingga siswa mampu lebih mandiri. Woolkfolk (1993) mengungkapkan, bahwa sekitar 70\% anak berbakat didunia pendidikan mempunyai intelegensi yang tinggi tetapi tidak menampilkan prestasi yang cemerlang dibanding dengan potensinya yang ada, disebabkan siswa tersebut tidak memiliki manajemen diri dalam belajar.

Secara umum deskrpsi teori manajemen diri dapat dilihat kedalam beberapa bagian diantaranya:

\section{a. Menentukan Tujuan}

Dalam pembelajaran tujuan sangat mempengaruhi hasil belajar, sebagaimana dalam teori Adlier dalam Siagian (1980) tentang tujuan fiktif (fictional goal) menyatakan bahwa perilaku seseorang diarahkan pada tujuan di masa yang disusun sendiri. Tujuan fiktif yang baik akan disusun oleh orang yang bersangkutan berdasarkan kreativitas dirinya sehingga tujuan itu menjadi unik bagi setiap orang. Subjektivitas dalam penyusunan tujuan fiktif berpengaruh signifikan terhadap keberhasilan belajar seseorang. Dengan arti lain apabila tujuan sudah diketahui maka tindakan orang tersebut akan lebih mantap dalam proses pembelajaran. Teori ini juga didukung dengan teori Bandura tentang teori motivasi dan kinerja (Bertal \& Sake, 1978). Dimana orang-orang akan berfikir positif apabila telah mengetahui tujuan yang akan dicapai. Tujuan ini disebutnya juga tujuan spesifik karena dalam rumusannya tujuan itu realistik, dan terukur.maka orang-orang yang sukses dengan tujuan ini dia akan meningkatkan keyakinan diri, keyakinan diri akan meningkatkan status sosial di kelas. Memperhatikan uraian di atas, jelas sekali bahwa dalam proses pembelajaran, siswa sangat penting untuk mampu menyusun tujuannya sendiri. Sebaliknya guru harus berusaha secara maksimal untuk membimbing siswa dalam menyusun tujuan belajarnya, sehingga bisa dijadikan pedoman perilakunya sehari-hari dikelas maupun di luar kelas. 


\section{b. Mencatat dan Mengevaluasi Kemajuan}

Untuk melatih dan mencapai tujuan pembelajaran siswa juga diajarkan mencatat semua apa yang telah dikerjakan dalam proses pembelajaran seperti telah melaksanakan beberapa tugas belajar, tanpa pengawasan guru. Dan seperti pembelajaran oleh teori perilaku Workman (1993: 177) yang disebutnya teori belajar pengontrol perilaku. Siswa mempunyai kartu kemajuan studi yang berfungsi membantu siswa untuk membagi-bagi tugas menjadi langkah-langkah lebih kecil, menentukan urutan terbaik untuk melengkapi langkahlangkah dan merekam kemajuan seharihari dengan menetapkan tujuan seharihari. Teori ini didukung juga dengan teori Morgan (1985) mengkombinasikan penetapan tujuan, pencatatan diri, dan evaluasi diri teori ini disebutnya dengan teori belajar monitoring. Dimana siswa sudah mempunyai tujuan belajar sendiri untuk mencapai tujuan dengan alat monitoring sebagai tolak ukur pelajaran dilakukan. Siswa di suruh melakukan sendiri urutanurutan pembelajaran sampai melakukan evaluasi secara sendiri.

\section{c. Penguatan Diri}

Langkah terakhir dalam manajemen diri adalah penguatan diri (self reinforcement) teori belajar Hayes dan kawankawan mengungkapkan salah satu penguatan dalam manajemen diri adalah self reinforcement, dengan beberapa kegiatan awal seperti, observasi diri sebelum belajar, mengambil keputusan dalam menetap-kan tujuan, dan merespon diri dalam setiap pembelajaran. Dalam pembe-lajaran manajemen diri siswa ketiga tujuan diatas yang ingin dicapai dalam manajemen diri siswa dapat dilihat pada tabel berikut ini:

Tabel 1: Penguatan Diri

\begin{tabular}{l|l}
\hline Indikator & Sub indikator manajemen \\
\hline
\end{tabular}

\begin{tabular}{|c|c|}
\hline $\begin{array}{l}\text { manajemen } \\
\text { diri siswa }\end{array}$ & diri siswa \\
\hline $\begin{array}{l}\text { Kemampuan } \\
\text { menyusun } \\
\text { tujuan }\end{array}$ & $\begin{array}{l}\text { a. Banyak tujuan yang } \\
\text { disusun } \\
\text { b. Ketepatan } \\
\text { mempresentasikan tujuan } \\
\text { c. Kualitas tujuan } \\
\text { d. Frekuensi modifikasi } \\
\text { tujuan }\end{array}$ \\
\hline $\begin{array}{l}\text { Kemampuan } \\
\text { memonitor dan } \\
\text { mengevaluasi } \\
\text { kegiatan }\end{array}$ & $\begin{array}{l}\text { a. Ketepatan cheklist } \\
\text { tentang tugas yang } \\
\text { diselesaikan } \\
\text { b. Ketepatan catatan waktu } \\
\text { penyelesaian tugas } \\
\text { c. Ketepatan pencatatan } \\
\text { waktu memulai dan } \\
\text { mengakhiri kegiatan } \\
\text { d. Frekuensi mendapat } \\
\text { bimbingan dari guru } \\
\end{array}$ \\
\hline $\begin{array}{l}\text { Kemampuan } \\
\text { memberikan } \\
\text { penguatan diri }\end{array}$ & $\begin{array}{l}\text { a. Ketepatan kinerja dengan } \\
\text { penguatan } \\
\text { c. Kualitas jenis penguatan } \\
\text { d. Frekuensi pemberian } \\
\text { penguatan }\end{array}$ \\
\hline
\end{tabular}

Dari tabel ini dapat dilihat gambaran antara fungsi manajemen diri siswa terhadap proses pembelajaran beserta tujuan pembelajaran yang diharapkan.

\section{ANALISA MANAJEMEN DIRI SISWA TERHADAP PEMBELAJARAN PAI}

Sebelum penulis menguraiakan bahasan manajemen diri siwa dalam proses pembelajaran, akan penulis singgung sedikit prinsip manajemen dalam pendidikan persekolahan Islam, Bahwasanya pendidikan-dalam Islam diyakini sebagai salah satu upaya peningkatan kualitas manusia termasuk peserta didik, maka pendidikan Islam sebagai institusi (lembaga) pendidikan yang merupakan wadah tempat proses pendidikan dilakukan sangat dituntut untuk melaksanakan prinsip-prinsip manajemen dalam pembelajaran, prinsip ini pula yang telah dilakukan dalam pembelajaran masa keemasan pendidikan Islam seperti mengembangkan prinsip, disiplin, jujur, adil, taanggungjawab, ikhlas dan amanah. Spirit inilah yang dapat 
dijadikan konsep dasar pembentukan manajemen diri pada siswa (Woolfolk, 1993).

\section{Proses Pembelajaran Secara Umum}

Proses pembelajaran secara umum merupakan suatu proses kegiatan di mana elemen-elemen pembelajaran dalam upaya mengembangkan pengetahuan siswa, keterampilan serta pengalaman pererta didik (Suparman dalam mahidin (2003: 45). Popham dan Baker (1970) mengemukakan bahwa proses pembelajaran merupakan suatu cara untuk mencapai tujuan belajar yang telah direncanakan. Dalam hal ini pembelajaran diartikan sebagai salah satu cara atau metode yang dapat ditempuh untuk menyiapkan rangkaian kegiatan belajar.

Romiszowsky (1981) menyatakan bahwa pembelajaran adalah suatu proses mengajar yang diarahkan untuk mencapai tujuan yang telah direncanakan yang di di dalamnya terkandung proses belajar mengajar yang akan memungkinkan penguasaan pengetahuan baru pada siswa, di samping keterampilan serta sikap siswa. Sedangkan Sardiman (2003: 37) menyatakan, terdapat unsur penentu lainnya dalam proses pembelajaran selain siswa yakni guru yang pada prinsipnya berperan sebagai fasilitator yang menjadikan siswa sebagai subjek pendidikan yang diberi kemudahankemudahan untuk belajar melalui proses pembelajaran.

Dilihat dari makna pembelajaran, Oemar Hamalik menyatakan bahwa pembelajaran itu merupakan suatu kombinasi yang tersusun di dalamnya terdapat unsurunsur manusiawi, material dan fasilitas serta perlengkapan yang ditunjang dengan proses yang saling mempengaruhi dalam mencapai tujuan belajar yang telah disepakati bersama. Guru dan siswa sebagai unsur utama terlibat yang merupakan suatu penggerak terlaksananya pembelajaran yang baik. Dalam proses pembelajaran, guru harus berusaha memberikan ukuran-ukuran yang ingin dicapai oleh siswa, dan siswa harus memahami ukuran-ukuran dan tujuan-tujuan yang harus dicapai dalam pembelajaran, dalam hal ini diperlukan monitoring untuk mengontrol apakah pelajaran itu tercapai sesuai yang diharapkan.

Suke Silverius (2003) menyebutkan bahwa kegiatan belajar mengajar perlu memperhatikan berbagai prinsip antara lain berpusat pada; belajar dengan melakukan, mengembangkan kreativitas siswa; mengembangkan kemampuan menggunakan ilmu dan teknologi; mengem-bangkan keterampilan pemecahan masalah.

Berdasarkan beberapa pendapat di atas dapat disimpulkan bahwa proses pembelajaran adalah situasi pendidikan yang merupakan interaksi antara peserta didik dan pendidik, yang di dalamnya terdapat elemenelemen pembelajaran sebagai daya kontrol pembelajaran. Dan daya kontrol atau monitoring yang dilaksanakan oleh guru dan siswa inilah yang dikatakan sebagai manajemen diri dalam proses pembelajaran.

2. Proses Pembelajaran Pendidikan Agama Islam

Proses pembelajaran pendidikan agama Islam di kelas, diharapkan dapat mencapai tujuan PAI. Untuk memahami bagaimana proses pembelajaran yang mampu mencapai tujuan itu sangat diperlukan proses yang baik dengan memberikan pemahaman yang baik pada peserta didik, dapat diketahui antara lain dari teknik/metode yang diterapkan guru serta peserta didik adalah melaksanakan manajemen diri yang digunakannya dalam melaksanakan proses pembe-lajaran di kelas.

Dalam pencapaian metode/teknik dalam mengajar, guru dan peserta didik dapat menggunakan media kontrol untuk mencapai tujuan pembelajaran PAI. Sebagaimana dilakukan oleh Ahmad Tafsir dengan metode pembelajaran PAI dengan sistem kontrol siswa dan guru menjalankan beberapa prinsip proses pembelajaran seperti; prinsip mem-berikan suasana kegembiraan, prinsip memberikan layanan dan santunan dengan lemah lembut; prinsip kebermak-naan bagi anak didik; prinsip prasyarat (apersepsi); prinsip komunikasi 
terbuka; prinsip memberikan penge-tahuan yang baru dan prinsip memberikan model perilaku yang baik serta prinsip praktek (pengalaman) secara aktif.berdasarkan prinsip diatas, maka dapat dilihat bahwa perlunya sistem kontrol (manajemen) diri siswa dalam proses pembelajaran.

3. Nilai manajemen diri dalam pembe-lajaran Pendidikan Agama Islam (PAI)

Internalisasi materi pendidikan agama Islam merupakan upaya atau proses penanaman nilai-nilai yang terkandung dalam syariat Islam. Materi pelajaran agama khususnya agama Islam, syarat dengan nilainilai yang sangat berguna bagi kehidupan manusia pada umumnya dan khususnya bagi peserta didik. Nilai-nilai tersebut berkaitan erat dengan kehidupan peserta didik. Nilainilai tersebut berkaitan erat dengan kehidupan peserta didik baik sebagai makhluk individu dan makhluk sosial.

Shihab (1998) mengemukakan bahwa materi Pendidikan Agama Islam juga mengandung unsur-unsur tugas dan tanggung jawab manusia sebagai makhluk ber-Tuhan yang memiliki kewajiban untuk bertaqwa dan beriman, sehingga mereka terdorong untuk dapat belajar lebih giat dalam mencapai tujuan belajar dan tujuan hidupnya terutama pengabdian kepada Allah SWT. Sebagaimana tujuan pembelajaran PAI adalah untuk menerapkan dan mengamalkan nilai-nilai yang terkan-dung dalam materi tersebut, juga harus memberikan kemungkinan bagi pengembangan potensi keberagamaan peserta didik dengan sebesar-besarnya. Proses pembelajaran juga harus mengem-bangkan dimensi keberagamaan peserta didik. Dalam pengembangan potensi tersebut, guru dapat menanam-kan nilai-nilai pengendalian diri dalam materi pelajaran, menggunakan metode yang tepat agar siswa saling menghargai sesama siswa maupun menciptakan situasi yang kondusip dalam interaksi proses pembelajaran. Tujuan utama PAI adalah nilai-nilai agama khususnya akhlak pada sistem persekolahan dapat dilakukan dalam proses pembelajaran hal ini perlu dilakukan sebagai salah satu tugas profesionalitas guru, yakni mengajar sekaligus mendidik anak menuju kedewasaan berfikir bersikap dan perilaku yang dilandasi dan dijiwai akhlak mulia.

Dari uraian di atas dapat diambil kesimpulan bahwa salah satu aspek penunjang keberhasilan proses pembelajaran PAI dapat dilihat dari seberapa banyak sistem pengendalian diri oleh guru dalam proses pembelajaran dan seberapa banyak siswa memahami tujuan pembelajaran yang dilakukan dengan cara konsep diri diatas atau manajemen diri bagi siswa yang bersangkutan.

4. Aplikasi Manajemen Diri Dalam Pembelajaran Pendidikan Agama Islam(PAI)

Pikiran-pikiran utama yang ter-dapat dalam prinsip, strategi. Dan tahapan KBM PAI mencerminkan bahwa pembelajaran PAI, tidak seseder-hana dalam proses penyampaiannya. Tetapi lebih jauh dari itu, fungsi dan peran PAI sampai pada pembentukan akhlak karimah dan kepribadian seutuhnya (kaffah). Konsekwensi dari ini, maka pengembangan pembelajaran PAI memerlukan modelmodel pembelajaran yang sesuai dengan tuntutan isi dan hasil yang diharapkan. Dan perlu perhatian pula prinsip-prinsip yang menyokong pembelajaran PAI, salah satunya adalah manajemen diri siswa yang akan belajar PAI. Prinsip-prinsip tersebut akan digambarkan dalam skenario pembelajaran. Dari skenario itu guru diharapkan dapat memotivasi dan mengontrol siswa dari aspek manajemen diri yang diharapkan akan mencul setelah melalui proses pembelajaran.

Untuk melihat proses manajemen diri dalam proses pembelajaran PAI, dapat dilihat dari skenario pembelajaran PAI pada siswa SLTP dibawah ini: 


\begin{tabular}{|c|c|c|c|c|}
\hline $\begin{array}{l}\mathrm{NO} \\
\mathrm{KD}\end{array}$ & $\begin{array}{l}\mathrm{NO} \\
\mathrm{HB}\end{array}$ & $\begin{array}{l}\text { NO } \\
\text { Ind }\end{array}$ & Skenario Pembelajaran 1 & $\begin{array}{l}\text { Alokasi } \\
\text { Waktu }\end{array}$ \\
\hline 1 & 1.1 & 1.1 .1 & $\begin{array}{l}\text { Guru membuka pelajaran dengan menyinggung nilai-nilai yang } \\
\text { diperoleh pada semester yang lalu, kemudian bertanya kepada anak } \\
\text { yang mendapat nilai yang baik, tentang bagaimana ia belajar hingga } \\
\text { mendapat nilai yang baik. Guru bertanya tentang apa yang } \\
\text { dilakukan siswa-siswa setelah pulang sekolah. Guru membuat list di } \\
\text { papan tulis. Lalu guru mengajak siswa untuk menemukan kegiatan } \\
\text { mana yang menunjukkan sebagai seorang pelajar. } \\
\text { Guru menentukan tujuan pembelajaran apa yang akan dicapai dan } \\
\text { perilaku apa yang dihasilkan setelah proses pembelajaran selesai. } \\
\text { Sementara siswa membuat tujuannya sendiri sesuai dengan tuntutan } \\
\text { materi, setelah itu siswa mengisi ceklist yang sudah disesuaikan } \\
\text { dengan materi yang sedang berlangsung. } \\
\text { Guru memberikan stimulus seperti pertanyaan pertanyaan: } \\
\text { 1. Sebutkan satu saja contoh kebiasaan baik yang menurutmu, } \\
\text { sudah dilakukan sebagai seorang siswa? Bisakah kau ingat } \\
\text { bagaimana awalnya hal-hal belajar positif itu menjadi } \\
\text { kebiasaan? } \\
\text { 2. Apakah kau mengenal seseorang yang memiliki kebiasaan } \\
\text { buruk dalam belajar? Menurutmu apakah ia akan bisa } \\
\text { mengubahnya? Bagaimana caranya? } \\
\text { 3. Apakah kau punya kebiasaan buruk sebagai seorang pelajar } \\
\text { yang harus diperbaiki? } \\
\text { Setelah mengajukan pertanyaan tersebut guru membagikan } \\
\text { selembar kertas jilid/kertas jeruk kepada siswa untuk orang tua } \\
\text { mereka, dengan sebelumnya sudah diberi tulisan " buatlah daftar } \\
\text { kebiasaan yang perlu diperbaiki oleh siswa" diskusikan dan buatlah } \\
\text { rencana bulanan untuk mengubahnya oleh bapak/ibu sebagai orang } \\
\text { tua yang baik! Jelaskan pada mereka bahwa jawaban dari orang tua } \\
\text { tidak akan diberi penilaian. } \\
\text { Guru memancing tanya jawab tentang perbuatan seorang muslim } \\
\text { yang baik selama satu hari dan membuat perumpamaan- } \\
\text { perumpamaan untuknya ( seperti seorang muslim ibarat lebah) }\end{array}$ & \\
\hline
\end{tabular}

\begin{tabular}{l|l|l|c|c}
\hline 1 & 1.2 & 1.1 .2 & Skenario kontrol dalam pembelajaran PAI & $\begin{array}{c}\text { Alokasi } \\
\text { Waktu }\end{array}$ \\
\hline & & & 1. Menciptakan ketenangan dalam berfikir, lingkungan kelas & \\
\hline
\end{tabular}




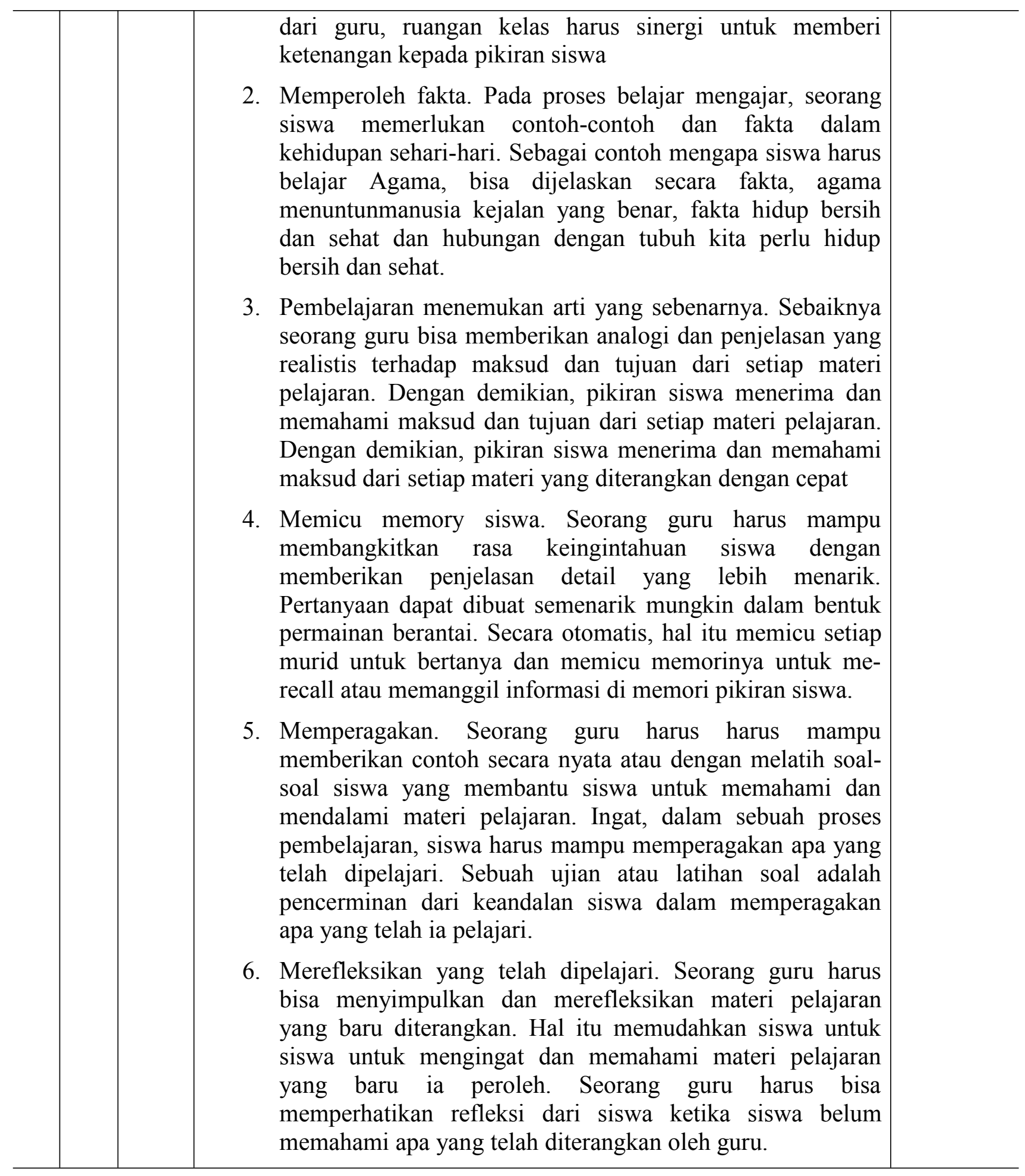


5. Indikator Manajemen Diri siswa dan Penerapannya Pada Sekolah, Lembaga

Dalam bahasan terakhir ini akan digambarkan bagaimana standar manajemen diri siswa dan penerapannya dalam sekolah atau lembaga yang melaksanakan baik dalam lembaga umum atau lembaga pendidikan Islam. Menurut Abudinata (2003), apabila dilihat dari sekolah atau lembaga yang menerapkan manajemen diri siwa maka dapat dilihat ciri-ciri proses global pembelajaran sebagai berikut:

a. Ditinjau dari penstrukturan waktu sekolahnya dapat dikatakan baik apabila fekuensi waktu dalam sehari disekolah itu tidak sewenang-wenang (45 menit untuk ini, 45 menit untuk itu, dan seterusnya) melainkan didasarkan pada apa yang perlu dilakukan siswa. Siswa tidak dituntut semata-mata untuk memenuhi waktu dalam pelajaran, melainkan menguasai keterampilann siswa diarahkan untuk mengorganisasi waktunya sendiri

b.Ditinjau dari penstrukturan aktivitas, sekolah dapat dikatakan baik adalah Aktivitas-aktivitasnya disesuaikan dengan kebutuhan siswa secara perorangan baru kelompok. Antara satu siswa dan siswa lainnya tidak dituntut untuk mengikuti aktivitas yang sama. Selalu melibatkan siswa setiap proses pembelajaran Aktivitasnya tidak terbatas pada sebuah gedung, melainkan juga mencakup semua sumber belajar pada masyarakat. Aktivitas-aktivitasnya memenuhi semua perbedaan latar belakang dan kemampuan siswa

c. Ditinjau dari pendefenisian kecerdasan, pengetahuan atau perilaku sekolah dapat dikatakan baik apabila proses belajar-mengajar yang dikelolanya lebih menekankan pada proses inkuiri, pemecahan masalah dan penelitian daripada memorisasi siswa dijauhkan dari kebiasaan menerima pelajaran secara pasif. Berbagai latihan ber-komunikasi dilatihkan kepada siswa. Kepada siswa ditekankan untuk menggunakan ilmu dalam kehidupan sehari-hari, bukan sekedar memperoleh ilmu demi ilmu. Siswa mengakui adanya perkembangan pengetahuan diberbagai bidang dan mencoba mempertimbangkannya dalam mendefi-nisikan pengetahuan. Pengetahuan diri sendiri merupakan bagian dari definisi pengetahuannya (siswa).

d. Ditinjau dari segi evaluasi sekolah dapat dikatakan baik apabila dalam proses evaluasinya; lebih menekankan pada upaya memberikan balikan yang men-dorong; digunakan pendekatan yang humanistik dan perorangan; mencakup aspek yang komprehensif; menentukan terlebih dahulu jenis perilaku yang diinginkan sekolah; khusus guru dan administrator digunakan evaluasi prosedur yang kontruktif

e. Ditinjau dari suvervisi dan pengawasan siswa sekolah, dapat dikatakan baik apabila; Guru dan siswanya melakukan upaya-upaya yang kolaboratif; siswanya diberi kesempatan untuk mensupervisi dirinya sendiri; jumlah yang ditangani seorang supervisor tidak banyak, sehingga masalah personalnya bisa ditangani.

f. Ditinjau dari perbedaan peran sekolah, dapat dikatakan baik adalah: semua gurunya selalu mengembangkan ide mengenaki masyarakat belajar dimana fungsi guru lebih sebagai seorang koordinator dan fasilitator; berbagai peran dalam mengajar tidak hanya dimainkan hanya oleh guru; siswa bukan dianggap sebagai objek pada setiap aktivitas, melainkan didorong untuk aktif membentuk pengalamannya sendiri; siswa tidak secara konstan ditempatkan dalam peran-peran kompetitif, melainkan juga kolaboratif.

g. Ditinjau dari pertanggungjawaban ter-hadap masyarakat, sekolah dikatakan baik apabila personelnya:Lebih mene-kankan pada partisipasi masyarakat, daripada paternalistik birokratik; tidak takut mempertanggungjawabkan perfor-mansinya; ditinjau dari pertanggung-jawaban terhadap masa depan sekolah, dapat dikatakan baik apabila personilnya; memiliki konsep tentang pengetahuan, sikap dan keterampilan yang diorientasikan pada masa depan; enginterpretasikan tanggung 
jawabnya pada masa depan sebagai tanggung jawab kepada siswa, baru kemudian kepada institusi

\section{SIMPULAN}

Berdasarkan uraian sebelumnya maka dapat disimpulkan sebagai berikut:

1. Manajemen diri siswa yang dimaksud dalam tulisan ini adalah kemampuan personal siswa SLTP dalam mencapai tujan tertentu termasuk pembelajaran harus dikelola dengan tepat dan bisa melalui orang lain seperti guru dan lainnya, menurut konsep manajemen, bahwa manajemen diri termasuk sebuah keterampilan dan keahlian seseorang yang terdapat dalam diri siswa.

2. Salah satu cara yang dapat dilakukan sebagai aplikasi manajemen diri siswa dalam proses pembelajaran dapat dilihat dari indikatonya; seperti kemampuan siswa menentukan tujuan pembelajaran, kemampuan memonitor dan mengevaluasi tujuan pembelajaran, dan mampu memotivasi dan memberikan penguatan pada diri sendiri.

3. Pendidikan Agama Islam (PAI) sebagai suatu subjek mata pelajaran bagi siswa SLTP dilihat dari segi teori dan materi pembelajaran sangat memungkinkan siswa untuk mencapai tujuan pembelajaran yang baik, karena PAI itu sendiri adalah sebagai spirit munculnya nilai-nilai manajemen pada diri siswa sebagaimana diketahui bahwa prinsip manajemen dalam pendidikan Islam itu yang pertama adalah disiplin yang sangat relevan dengan konsep manajemen diri siswa.

\section{DAFTAR RUJUKAN}

Abuddinata. 2003. Manajemen Pendidikan Mengatasi Kelemahan Pendidikan Islam di Indonesia. Predana Media: Jakarta.
Abdullah, A.S. 1994. Educational Theory a Quranic Outlook. Ter. Teori-teori Pendidikan Berdasarkan Al-Quran. Jakarta : Renika Cipta.

Asnawir. 2006. Manajemen Pendidikan, IAIN IB Press, Padang.

Bafadal, F. 2003. Manajemen Peningkatan Mutu Sekolah Dasar, dari Sentralisasi menuju Desentralisasi, Jakarta: Bumi Aksara.

Bertal, D. \& Sake, L. 1978. Social Pschology of Education. New York: Jhon Wiley \& Son.

Djamarah, S.B. 2003. Guru dan Anak Didik Dalam Interaksi Edukatif, Jakarta: Renika Cipta.

Good, T.L \& Brophy, J.E. 1990. Edcational Psychology. New York: Longman.

Jafar M. 1981. Beberapa Aspek Pendidikan Islam, Surabaya : Al-Ikhlas.

James H. Donelly, J.H., et-al. 1984. Fundamental of Managemen, Texas Business Publication, Inc.,

Lembaga Kajian Manhaj Tarbiyah. 2007. Manhaj Tarbiyah 1427 H. Jakarta: Tarbiyah Pustaka

Mahidin. 2003. Kontribusi Disiplin dan persepsi Tentang Pembelajaran terhadap kefrofesionalan Staf Pengajar Fakultas Tarbiyah IAIN-SU Medan, Tesis UNP Padang Tahun 2003

Madden, T. L. 2002. Fire Up Your Learning, Petunjuk Belajar, yang d Dipercepat Untuk Umur 12 Tahun Keatas, Jakarta: Gramedia Pustaka Utama.

Muhaimin. 2005. Pengembangan Kurikulum Pendidikan Agama Islam di Sekolah, Madrasah dan Perguruan Tinggi. Jakarta: Raja Grafindo Persada

Ramayulis. 2011. Ilmu Pendidikan Islam, Jakarta Kalam Mulia.

Reynol, M.C. 1990. Knowledge Behavior the Beginning Teacher. New York. 
Rusman. 2006. Modul Pendekatan dan model Pembelajaran, Bandung: Universitas Pendidikan Indonesia.

Rusman. 2009. Manajemen Kurikulum : Seri Manajemen Sekolah Bermutu, Jakarta: PT Raja Grafindo Persada.

Shihab, Q. 1998. Membumikan Al-Quran Fungsi dan Peran Wahyu dDalam Kehidupan Masyarakat, Bandung: Mizan.

Siagian, S.P. 1980. Filsafat Administrasi, Jakatra: CV. Masagung.

Siagian, S.P.1998. Manajemen Abad 21.Cet. 1. Jakarta: Bumi Aksara.

Silverius,S. 2003. Kurikulum Masa Depan: Dalam Tujuh Isi Pendidikan, Jakarta, Balitbang Departemen Pendidikan Nasional.
Sudjana, N. 1998. Dasar-dasar Proses Belajar Mengajar, Bandung: TP.

Suhandana, A. 1997. Pendidikan Nasional sebagai Sumber Instrumen Pengembangan SDM, Bandun: Mizan.

Suit, Y. 1999. Sikap Mental dalam Manajemen SDM, Jakarta: Balai Pustaka.

Tilaar, H.A.R. 1997. Manajemen Pendidikan Nasional, Bandung: PT Remaja Rosdakarya.

Winardi. 1992. Manajemen Perilaku Organisasi. Bandung: PT Citra Aditya Bakti.

Woolkfolk, A. 1993. Educational Pschology. Bootson.

Zinun, B. 1993. Manajemen Sumber Manusia, Jakarta Gunung Agung.

Soekidjo. 2003. Pengembangan Sumber Daya Manusia, Jakarta; Renika Cipta

Sudrajat, A. 2008. Lesson Study Untuk Meningkatkan Proses dan Hasil Pembelajaran. Tersedia di http:// akhmadsudrajat.wordpress.com 